\title{
The Impact of Executives' Background on the Financial Constraints: Perspective from Political Connection and Financial Connection
}

\author{
Yang Mingjing \\ School of Economics and Management, Beijing Jiaotong University, Beijing 100044, China
}

\begin{abstract}
Based on statistics of A-share enterprises in the period of 2007 to 2010, our literature mainly discuss the impact of executives' political and financial connection on the financial constraints of the firms with different properties of ownership and in locations with different degree of marketization. Our study vindicates that private enterprises located in areas with low degree of marketization, executives with financial connections can alleviate the financial constraints. However, in areas with high degree of marketization executives with political connections can alleviate the financial constraints. Furthermore, in state-owned enterprises, executives with political connections can alleviate the financial constraints. Therefore, our study contributes to existing literatures regarding executive background and financial constraints. And we also provide instructions for firms that want to moderate financial constraints by recruiting new executives.

Index Terms - politicalconnection, financial connection, degree of marketization, financial constraints
\end{abstract}

\section{Introduction}

Financial constraints theory is originated and developed from the investing theory. Financial constraints have substantial impact on the survival, growing, and development of enterprises. It is generally believed that in our country financial resources are usually allocated to state-owned enterprises, and hence private enterprises are usually confronted with serious financial constraints. However, recent studies indicate that state-owned enterprises are also confronted with financial constraints (Dai et al, 2012), suggesting that financing constraint is a general problem. Nevertheless, the rapid growth in both state-owned and private enterprises indicates that both of them have developed strategies to alleviate the financial constraints. Specifically, governmental connections (Luo et al, 2008) and bank and security connections (Deng et al, 2011) are able to alleviate financial constraints in private enterprises.

Furthermore, since the degree of marketization varies from district to district in China (Sun et al, 2005), the degree of marketization is also prone to have influence on financial constraints.

To shed some light on the academic field, our study mainly regards the impact of executives' political and financial connection on the financial constraints of the firms with different properties of ownership and in locations with different degree of marketization.

\section{Literature Review}

The existing literatures in China regarding financial constraints mainly focus their studies on the measurement of financial constraints and the impact of financial constraints on the firm performance. Specifically, studies focusing on the measurement of financial constraints mainly use FHP model (Fazzari et al, 1988) and KZ model (Kaplan and Zingales, 1997). Simultaneously, studies mainly investigate the impact of financial constraints on firm value (Gu, 2011), investment behavior (Li, 2007; Zhou, 2012), and exporting (Yu, 2012). However, only a few existing literatures in China rarely investigate the causes and contributory factor to financial constraints. In these literatures, Luo and Chen (2012) investigate the impact of the degree of marketization, executive background, and the property of ownership of the firm on financial constraints. Caoet al (2012) use three indicators, education, expertise, and age, to represent executive background, and study the impact of executive background on debt financial structure and debt duration structure. Sun (2005) vindicates that the proportion of longterm debt decreases with the increasing degree of marketization. Furthermore, Sun (2005) contends that rule is due to the different degree of government intervention with different degree of marketization.

The existing literatures in China regarding financial constraints mainly use indicators, such as education, expertise, and age, to represent executive background (Cao, 2012; Du, 2011; Ji, 2011) and rarely study the political connections and financial connections. Furthermore, the few literatures studying political connections and financial connections usually focus their studies on the impact of political connections and financial connections on financial performance (Wei, 2007), investment behaviors (Hao, 2012), and diversification Strategies (Hu, 2008; Wang, 2012).

Although some of the existing literatures study the impact of political connections and financial connections on the financial constraints, these literatures never consider the different impact of firms with different properties of ownership and in locations with different degree of marketization. To illuminate the academic field in some degree, our study mainly regards the impact of executives' political and financial connection on the financial constraints of the firms with different properties of ownership and in locations with different degree of marketization. 


\section{Hypotheses Development}

Bian and Qiu (2000) contend that enterprises are not isolated entities but nodes in the economic network. Therefore, it is an important capability of corporations to take advantage of those connections to obtain scarce resources. Specifically, corporations can use political connections and financial connections of their executives to obtain financial resources.

Financial connections can assist private enterprises to build intense relationships with financial institutions, supervision department, and outside investors. Therefore, corporations with strong financial connections are able to influence the decisions of financial institutions, supervision department, and outside investors and hence ameliorate the financial environment.

In areas with low degree of marketization, although the governments intervene in the allocation of loans, since the governments make decisions to optimize its own performance, they always allocate more financial resources to state-owned enterprises. Furthermore, in areas with low degree of marketization, the governments are always impoverished and hence are not able to think about its long-term performances and help private enterprises with political connections. Therefore, in areas with low degree of marketization, political connectionof private enterpriseswill be useless to alleviate financial constraints. However, the interests of financial institutions are not all the same. Therefore, financial institutions are inclined to furtively help private enterprises with financial connections, because those firms can bring them with profits. Consequently, in areas with low degree of marketization, financial connectionof private enterprises will be useful to alleviate financial constraints. Accordingly, it is hypothesized that:

H1a: In areas with low degree of marketization, executives' financial connections private enterprises can alleviate financial constraints.

H1b: In areas with low degree of marketization, executives' political connections of private enterprises cannot alleviate financial constraints.

In areas with high degree of marketization, although the governments do not intervene in the allocation of loans, they still make decisions to optimize its own performance. And they are always wealthy and hence are able to think about its longterm performances and help private enterprises with political connections. For instance, since in areas with high degree of marketization, the governments usually help private enterprises to overcome difficulties, because the existence of these private firms is important to the economic environment of those areas $(\mathrm{Li}, 2009)$. Therefore, in areas with high degree of marketization, political connectionof private enterprises will be useful to alleviate financial constraints. However, in areas with high degree of marketization, financial institutions do not need to furtively give loans to private enterprises. Therefore, every private enterprise is able to get appropriate loans from financial institutions. Consequently, in areas with high degree of marketization, financial connectionof private enterprises will be useless to alleviate financial constraints. Accordingly, it is hypothesized that:

H2a: In areas with high degree of marketization, executives' political connections of private enterprises can alleviate financial constraints.

H2b: In areas with high degree of marketization, executives' financial connections of private enterprises cannot alleviate financial constraints.

Unlike private enterprises, the performances of stateowned enterprises are intensely related with the performances of governments. Therefore, governments are inclined to help state-owned enterprises. Furthermore, state-owned enterprises with more political connections always have more power over the government. Since the government can more or less influence the financial policies and loan decisions, political connectionof private enterprises will be useful to alleviate financial constraint. However, since state-owned enterprises always use political method to obtain financial resources, financial connections are relevantly not important. Accordingly, it is hypothesized that:

H3a: Executives' political connections of state-owned enterprises can alleviate financial constraints.

H3b: Executives" financial connections of state-owned enterprises cannot alleviate financial constraints.

\section{Sample and Measurement of Variables}

\section{A. Sample}

Our study is based on the statistics of A-share enterprises in the period of 2007 to 2010.The statistics come from CSMAR database. To ensure the reliability of our study, we did several treatments to the statistics. Firstly, we eliminated the financial enterprises. Secondly, we eliminated ST enterprises and enterprises with negative equity. Thirdly, we eliminated enterprises with little information about executive background. Finally, we winsorize the statistics. Then, 4444 samples were obtained, including 1731 samples of private enterprise, 2731 samples of state-owned enterprise, 1058 samples in locations with low degree of marketization, and 3386 samples in locations with high degree of marketization.

\section{B. Independent variables}

Executives are defined to include the board of directors and managers but exclude the board of supervisors (Luo, 2008).

The financial connection (Fin) is defined as the proportion of executives with background of bank, trust, and security to the overall executives. It is defined to be stronger when the proportion is larger.

The political connection (Pol) is defined as the proportion of executives with background of NPC, government, and СРPCC to the overall executives. It is defined to be stronger when the proportion is larger.

The degree of marketization (FM) is defined as the overall grades of marketization in Fan (2011) specification. Since the statistics of 2010 are absent, the average value of the statistics of 2008 and 2009 are calculated to represent the 
statistics of 2010. Furthermore, locations whose percentiles are higher than 50 are defined as locations with high degree of marketization whereas locations whose percentiles are less than 50 are defined as locations with low degree of marketization.

\section{Dependent variables}

Financial constraint is evaluated by an index. The index is obtained by Logistic regression, and the construction of the index will be discussed in fifth section.

\section{Control variables}

Scale of the enterprise (Size), equity ratio of investment (Eqi), financial expense rate (Cost), and slack (Slack) are considered as control variables.

Table1 presents the variablesof the entire paper.

TABLE 1 Variablesof the Entire Paper

\begin{tabular}{|l|l|l|}
\hline Variable & Code & Definitions and Explanations \\
\hline Coverage & Cover & $\begin{array}{l}\text { (Net profit + Tax+ Financial expenses) } \\
\text { Financial expenses }\end{array}$ \\
\hline Return on equity & ROE & Net profit/Equity \\
\hline Cash asset ratio & CASH & Cash/Assets \\
\hline Leverage & LEV & Liabilities/Assets \\
\hline Current Ratio & CR & Current assets/ Current liabilities \\
\hline Financial connection & Fin & $\begin{array}{l}\text { Executives withFinancial connection } \\
/ \text { Overall Executives }\end{array}$ \\
\hline Political connection & Pol & $\begin{array}{l}\text { Executives with Political connection } \\
/ \text { Overall Executives }\end{array}$ \\
\hline $\begin{array}{l}\text { Degree of } \\
\text { marketization }\end{array}$ & Fm & $\begin{array}{l}\text { From the } \text { NERI index of marketization of } \\
\text { China's provinces 2011 report }\end{array}$ \\
\hline Scale of the enterprise & Size & The natural logarithm of assets \\
\hline $\begin{array}{l}\text { Equity ratio of } \\
\text { investment }\end{array}$ & Eqi & $\begin{array}{l}\text { (Assets }- \text { Current liabilities }+ \text { Notes } \\
\text { payable }+ \text { Short-term loans + Non-current } \\
\text { liabilities due within one year) } / \text { Equity }\end{array}$ \\
\hline Financial expense rate & Cost & Financial expenses/Operating revenue \\
\hline Slack & Slack & $\begin{array}{l}\text { (Cash+Trading financial assets }+0.5 \\
\times \text { Inventories+0.7×Accounts receivable }- \\
\text { Short-term loans) } / \text { Assets }\end{array}$ \\
\hline First shareholder ratio & Fshr & First shareholder ratio \\
\hline
\end{tabular}

\section{Methodology and Model}

\section{A. Measurement of financial constraints}

Among all methods to evaluate the financial constraints, $\mathrm{KZ}$ is used in our study. Furthermore, according to Gu (2012) specification, Logistic regression is used. The specific steps are presented as follows.

Firstly, sample firms are divided into 3 groups whereby their coverage. The 1/3 firms with highest coverage constitute the group with low financial constraints whereas the $1 / 3$ firms with lowest coverage constitute the group with high financial constraints.

Secondly, the index of financial constraints is constructed.ROE, LEV, CR, and CASH were selected as indicators to evaluate financial constraints. Therefore, financial constraints are evaluated from three aspects, equity financing, debt financing, and internal financing.

Thirdly, the significances are tested. The significances of relationships between the four indicators and the firms' belonging to the 3 groups are tested to ensure that all the indicators are suitable to evaluate financial constraints.

Finally, Logistic regression is used to build and calculate the index of financial constraints.

$F C=\ln [p(Y=0) / p(Y=1)]=\alpha_{1} R O E+\alpha_{2} L E V+\alpha_{3} C R+\alpha_{4} C A S H$

\section{B. FC Index Construction}

Table 2 presents the results of the third step.

TABLE 2 Independent sample T-test

\begin{tabular}{|c|c|c|c|c|}
\hline \multirow[t]{2}{*}{ Group } & \multicolumn{2}{|l|}{ ROE } & \multicolumn{2}{|l|}{ LEV } \\
\hline & low & high & low & high \\
\hline N obs. & 1467 & 1467 & 1467 & 1467 \\
\hline Means & 0.142 & -0.023 & 0.437 & 0.595 \\
\hline t-value & \multicolumn{2}{|c|}{-38.408} & \multicolumn{2}{|c|}{27.395} \\
\hline Sig. & \multicolumn{2}{|c|}{$0.000^{* * * *}$} & \multicolumn{2}{|c|}{$0.000^{* * *}$} \\
\hline \multirow{2}{*}{ Group } & \multicolumn{2}{|l|}{ CR } & \multicolumn{2}{|c|}{$\mathrm{CASH}$} \\
\hline & low & high & low & high \\
\hline N obs. & 1467 & 1467 & 1467 & 1467 \\
\hline Means & 1.764 & 1.034 & 0.18 & 0.121 \\
\hline t-value & \multicolumn{2}{|c|}{-24.741} & \multicolumn{2}{|c|}{-17.845} \\
\hline Sig. & \multicolumn{2}{|c|}{$0.000^{* * *}$} & \multicolumn{2}{|c|}{$0.000^{* * * *}$} \\
\hline
\end{tabular}

Table 2 shows that the averages of four indicators all vary significantly from the group with low financial constraints and the group with high financial constraints, suggesting that four indicators are all suitable to evaluate financial constraints.

Table 3 and table 4 show the results of Logistic regression in the final step.

TABLE 3 Result of logisticregression

\begin{tabular}{|l|l|l|l|l|l|}
\hline & ROE & LEV & CR & CASH & $\begin{array}{l}\text { Chi-Square } \\
\text { (Sig.) }\end{array}$ \\
\hline coefficients & -58.037 & 11.248 & -1.008 & -5.555 & 3060.945 \\
\hline Sig. & $0.000^{* * *}$ & $0.000^{* * *}$ & $0.000^{* * *}$ & $0.000^{* * *}$ & $0.000^{* * *}$ \\
\hline
\end{tabular}

Notes: ${ }^{*},{ }^{* *}$ and ${ }^{* * *}$ denote significance levels at $10 \%, 5 \%$ and $1 \%$, respectively.

TABLE 4 Accuracy test for logistic model

\begin{tabular}{|l|l|l|l|l|}
\hline \multirow{2}{*}{ Group Sample } & \multicolumn{3}{|c|}{ logisticregression } \\
\cline { 3 - 5 } \multicolumn{2}{|c|}{} & low & high & Correct rate\% \\
\hline low & 1467 & 1350 & 117 & $92.0 \%$ \\
\hline high & 1467 & 80 & 1387 & $94.5 \%$ \\
\hline All & 2934 & & & $93.3 \%$ \\
\hline
\end{tabular}


Table 4 indicates that FC can be formulated into the following function.

$F C=-58.037 R O E+11.248 L E V-1.008 C R-5.555 C A S H$

Table 4 and table 5 indicate not only that the coefficients are significant but also show that the fitting degree and accuracy are high. The accuracy of the index in indicating firms to be included in the high or low financial constraints group reaches $93.3 \%$.

\section{Model Building}

$$
\begin{aligned}
& F C=\beta_{0}+\beta_{1} \text { Pol }+\beta_{2} \text { Fin }+\beta_{3} \text { Size }+\beta_{4} \text { Eqi }+\beta_{5} \text { Cost } \\
& +\beta_{6} \text { Slack }+\beta_{7} \text { Fshr }+\varepsilon
\end{aligned}
$$

The 6 hypotheses are tested with model (1). Furthermore, before testing, all the sample firms are divided again into 4 groups whereby the degree of marketization and the property of ownership.

\section{Empirical Results and Sensitivity Tests}

\section{A. Descriptive Statistics}

Table 5 presents the description of the main statistics. The table shows that the standard deviation of the index of financial constraints are considerable, suggesting that financial constraints vary from firm to firm in substantial extents. These differences can also be reflected by the standard deviation of coverage.

TABLE 5 Descriptive Statistics

\begin{tabular}{|l|l|l|l|l|l|}
\hline Variable & Mean & Median & Std. & Min & Max \\
\hline FC & -0.506 & -0.944 & 7.881 & -23.554 & 42.452 \\
\hline Fin & 0.079 & 0.056 & 0.118 & 0.000 & 1.000 \\
\hline Pol & 0.037 & 0.000 & 0.078 & 0.000 & 1.000 \\
\hline FM & 8.656 & 8.780 & 2.017 & 0.380 & 11.800 \\
\hline Cover & 14.366 & 4.576 & 35.495 & -13.176 & 261.924 \\
\hline Size & 21.796 & 21.651 & 1.178 & 19.523 & 25.504 \\
\hline Slack & 0.143 & 0.136 & 0.180 & -0.263 & 0.550 \\
\hline Fshr & 0.362 & 0.344 & 0.151 & 0.090 & 0.758 \\
\hline Cost & 0.028 & 0.019 & 0.031 & 0.000 & 0.195 \\
\hline Eqi & 0.558 & 0.552 & 0.190 & 0.146 & 0.974 \\
\hline
\end{tabular}

Additionally, correlation test is also conducted in our study. The result shows that although some independent or control variables are correlated, the correlations are all less than 0.4 . Therefore, the problem of multicollinearity will not spoil the regression.

\section{B. RegressionResults}

\begin{tabular}{|c|c|c|c|c|}
\hline & \multicolumn{4}{|c|}{ Degree ofmarketization } \\
\hline & \multicolumn{2}{|l|}{ low } & \multicolumn{2}{|l|}{ high } \\
\hline & Coefficients & t-value & Coefficients & t-value \\
\hline Constant & 75.51 & $7.299^{* * * *}$ & 47.971 & $9.948^{* * *}$ \\
\hline Fin & -5.451 & $-2.151^{* *}$ & 0.436 & 0.397 \\
\hline Pol & 6.723 & 1.263 & -4.482 & $-2.518^{* *}$ \\
\hline Size & -2.989 & $-6.473^{* * *}$ & -1.86 & $-8.849^{* * * *}$ \\
\hline Slack & -11.174 & $-3.891^{* * *}$ & -6.193 & $-5.454^{* * *}$ \\
\hline Eqi & -14.985 & $-5.920^{* * * *}$ & -14.953 & $-12.669^{* *}$ \\
\hline Fshr & -9.729 & $-3.291^{* * * *}$ & -3.843 & $-2.971^{* * * *}$ \\
\hline Cost & 44.749 & $3.251^{* * *}$ & 51.102 & $7.898^{* * * *}$ \\
\hline F-value & \multicolumn{2}{|l|}{$22.537^{* * * *}$} & \multicolumn{2}{|l|}{$81.706^{* * * *}$} \\
\hline Adj. $\mathrm{R}^{2}$ & \multicolumn{2}{|l|}{0.289} & \multicolumn{2}{|l|}{0.294} \\
\hline N obs. & \multicolumn{2}{|l|}{371} & \multicolumn{2}{|l|}{1360} \\
\hline
\end{tabular}

TABLE 6 Regression Results for Private Enterprises

Notes: ${ }^{*},{ }^{* *}$ and $^{* * * *}$ denote significance levels at $10 \%, 5 \%$ and $1 \%$, respectively.

Table 6 presents the regression result for private enterprises. Among firms in locations with low degree of marketization, the coefficient of Fin is -5.451 , and is significant in 0.05 levels of significance. Therefore, H1a is demonstrated. However,among firms in locations with low degree of marketization, the coefficient of Pol is not significant, demonstrating H1b.

Simultaneously, among firms in locations with high degree of marketization, the coefficient of Pol is -2.518, and is significant in 0.05 levels of significance. Therefore, H2a is demonstrated. However,among firms in locations with high degree of marketization, the coefficient of Fin is not significant, demonstrating H2b.

Consequently, to alleviate financial constraints, private firms in locations with low degree of marketization should recruit executives with financial connections whereas private firms in locations with high degree of marketization should recruit executives with political connections.

TABLE 7 Regression Results for State-owned Enterprises

\begin{tabular}{|l|l|l|l|l|}
\hline \multirow{4}{*}{} & \multicolumn{3}{|l}{ Degree ofmarketization } \\
\cline { 2 - 5 } & low & \multicolumn{3}{l|}{ high } \\
\cline { 2 - 5 } & Coefficients & t-value & Coefficients & t-value \\
\hline Constant & 49.508 & $6.422^{* * *}$ & 31.148 & 11.416 \\
\hline Fin & 4.068 & 1.302 & -3.338 & $-2.494^{* *}$ \\
\hline Pol & -16.964 & $-3.385^{* * *}$ & -8.901 & $-2.643^{* * *}$ \\
\hline Size & -1.709 & $-5.080^{* * *}$ & -1.05 & $-8.863^{* * *}$ \\
\hline Slack & -8.115 & $-3.479^{* * *}$ & -7.463 & $-8.976^{* * *}$ \\
\hline Eqi & -17.332 & $-7.797^{* * *}$ & -13.395 & - \\
\hline Fshr & -5.586 & $-2.429^{* * *}$ & -0.477 & $-0.523^{* * *}$ \\
\hline Cost & 36.825 & $3.332^{* * * *}$ & 17.818 & $3.699^{* * *}$ \\
\hline F-value & $36.700^{* * * *}$ & $94.633^{* * *}$ & \\
\hline Adj. ${ }^{2}$ & 0.267 & 0.245 \\
\hline N obs. & 687 & 2026 \\
\hline
\end{tabular}

Notes: ${ }^{*},{ }^{* *}$ and ${ }^{* * *}$ denote significance levels at $10 \%, 5 \%$ and $1 \%$, respectively. 
Table 7 presents the regression result for stateownedenterprises. Among firms in locations with low degree of marketization, the coefficient of Pol is -16.964 , and is significant in 0.01 levels of significance.Simultaneously, among firms in locations with high degree of marketization, the coefficient of Pol is -8.901, and is significant in 0.01 levels of significance. Therefore, H3a is demonstrated.

Among firms in locations with low degree of marketization, the coefficient of Fin is not significant, partially demonstrating H3b.However, among firms in locations with high degree of marketization, the coefficient of Fin is significant in 0.05 levels of significance. This result is to some extent not consistent H3b. We suppose this inconsistence is due to that the financial connections of state-owned firms are more powerful than financial connections of private firms, and hence can make financial institutes to give more financial supports than the equilibrium amount decided by the market.

\section{Sensitivity Tests}

In our study,the degree of marketization (FM) evaluated bythe overall grades of marketization in Fan (2011) specification. To test the robustness of our study, we conducted the analysis again using the grades financial industry of marketization in Fan (2011) specification to evaluate the degree of marketization and still obtain the same result.

\section{Conclusions}

Theoretically and empirically, our literature mainly investigates the impact of executives' political and financial connection on the financial constraints of the firms with different properties of ownership and in locations with different degree of marketization. Our study vindicates that private enterprises located in areas with low degree of marketization, executives with financial connections can alleviate the financial constraints. However, in areas with high degree of marketization executives with political connections can alleviate the financial constraints. Furthermore, in stateowned enterprises, executives with political connections can alleviate the financial constraints.

Based on the main results, some proposals are made for the practice of enterprises. Firstly, to alleviate financial constraints, private firms in locations with low degree of marketization should recruit executives with financial connections whereas private firms in locations with high degree of marketization should recruit executives with political connections. Secondly, to alleviate financial constraints, stateowned firms in locations with low degree of marketization should recruit executives with political connections whereas state-owned firms in locations with high degree of marketization should recruit executives with political or financial connections.

\section{References}

[1] Dai Guanglun, Den Jianping, Zeng Yong, "Financial development, government control and financial constraints”, Management Review, Vol.24, no.5, 2012.

[2] LuoDanglun, Zhen Liming, "Private political relationship and corporate financial constraints, Journal of Financial Research”, December 2008.

[3] Den Jianping, Zeng Yong, "Whether financial connection can alleviate the financial constraints of private enterprises”, Journal of Financial Research, August 2011.

[4] Sun Zheng, Liu Fengweiand Li Zengquan, "Market Development, Government Influence and Corporate Debt Maturity Structure”, Economic Research Journal, May 2005.

[5] GuQun, ZhaiShuping, "Correlations Between Financial Constraints and R\&D Investment, Growth of Hi-tech Enterprises”, Collected Essays on Finance and Economics, May 2011.

[6] Li Yan-xi, DuRui, GaoRui, LiNing, "Research on the Sensitivity between Financial Constraint and Investment Expenditure of Listed Companies in China”, Journalofmanagement sciences,Vol.1,no.2, 2007.

[7] Zhou Hon, WuGuizhen and Li Jitao, "Empirical Study of Financial Constraints' Influence on Chinese Enterprises' Investment Behavior”, Finance and Economics, May 2012.

[8] Yu Jianxun, "Impact of financial constraints on the behavior of export", Modern Management Science, March 2012.

[9] CaoYugui, SunJie, WangHuanhuan, “The Empirical Research on Enterprises' Executives Background Characteristics and Debt Financing”, Journal of North China Institute of Water Conservancy and Hydroelectric Power (Social SciencesEdition),Vol.28, no.3,2012.

[10] Luo Hong, Chen Lilin, "The impact of corporate financial constraints in the transformation of value-added tax", Accounting Research, December 2012.

[11] Du Gang, Zhen Lei, "Study on the relationship between the real estate industry executives' background characteristics and firm performance”, Economic Review, August 2011.

[12] JiJian, "Empirical Research on the Relationship between the Background Characteristics of Top Management Team (TMT) and Firm Performance", The Theory and Practice of Finance and Economics, May 2011.

[13] Wei Gang, Xiao Zezhong, "Nick Travlos and Zou Hong, Background of Independent Directors and Corporate Performance”, Economic Research Journal, March, 2007.

[14] HaoJunfu, Political Connection, "Excessive Investment and Corporate Performance — An Empirical Study based on the Background of Local Government's Administrative Intervention”, Industrial Technology \& Economy, December 2012.

[15] Hu Xuyang, Shi Jinchuan, "Political Resource and Diversification of Chinese Private Enterprises __ Evidence from the Largest 500 Private Enterprises”, China Industrial Economics, April 2008.

[16] Wang Bo, Wang Fanjun, Li Guodong, "The Research on Firm Diversification Strategy, Board Finance Affiliation and Corporate Performance”, Journal of Tianjin Normal University (Social Science), February 2012.

[17] BianYanjie, QiuHaixiong, "The social capital of enterprises and its effect”, Social Sciences in China, February 2000.

[18] Fan Gang, Wang Xiaolu, Zhu Hengpeng, "The NERI index of marketization of China's provinces 2011 report”, Economic Science Press,2011.

[19] Li Caixi, "Government subsidies and financial distress companies An Empirical Study Based on China's capital market”, Xiamen University,2009.

[20] Fazzari S.,G.Hubbard and B.Petersen, "Financing Constraints and Corporate Investment”, Brooking Papers of Economic Activities, January 1988.

[21] Kaplan S., L. Zingales, "Do Investment - cash Flow Sensitivities Provide Useful Measures of Financing Constraints?”, Quarterly Journal of Economics, Vol.24, no.5,1997. 